\section{Fertilizer Source Affects Nutrient Losses from Hybrid Bermudagrass during Surface Runoff}

\author{
Kayla R. Sanders ${ }^{1}$ and Jeffrey S. Beasley ${ }^{1}$
}

ADDITIONAL INDEX wORDs. best management practices, controlled-release fertilizer, Cynodon dactylon $\times$ C. transvaalensis, nitrogen, phosphorus, turfgrass management, water-soluble fertilizer

Summary. Controlled-release fertilizers (CRFs) provide an extended period of nutrient availability for turfgrass growth and may limit offsite nutrient losses compared with water-soluble fertilizers (WSFs). However, increasing temperatures and soil moisture accelerate nutrient release from many CRFs. As a result, turfgrass managers growing turfgrass in warm, humid climates with high rainfall question how effective CRFs are in reducing nutrient runoff losses while maintaining aesthetic quality. A study was conducted to examine the effect of three fertilizer treatments - an unfertilized control, a CRF applied at $87 \mathrm{lb} / \operatorname{acre}$ nitrogen $(\mathrm{N})$, and a WSF applied at $87 \mathrm{lb} /$ acre $\mathrm{N}$ as a split application $(43.5 \mathrm{lb} /$ acre $\mathrm{N})$ at 0 and 45 $\mathrm{d}$ after initial fertilization (DAIF) - on nutrient losses from 'Tifway' hybrid bermudagrass (Cynodon dactylon $\times$ C. transvaalensis) during surface runoff events. Rainfall simulations were conducted $3,28,56$, and 84 DAIF at an intensity of 3 inches per hour to induce 30 minutes of runoff. Water samples were analyzed for inorganic $\mathrm{N}$ and dissolved total phosphorus (DTP). Hybrid bermudagrass quality was similar among fertilizer treatments with CRF application, resulting in slightly higher quality. Across all fertilizer treatments, hybrid bermudagrass exhibited similar runoff initiation time and volumes within each rainfall simulation event. Nutrient losses from fertilized hybrid bermudagrass were greatest at the first runoff event at 3 DAIF, with WSF having the greatest losses. The subsequent application of WSF 45 DAIF did not result in greater $N$ and DTP losses compared with CRF application, most likely a result of water incorporation applied to prevent wilting. Hybrid bermudagrass fertilized with a single application of CRF resulted in $23.6 \%$ and 55.6\% reductions in cumulative inorganic N and DTP losses, respectively, compared with hybrid bermudagrass fertilized with the a split application of WSF.

A $s$ one of the most intensely managed crops (King, 2001), turfgrass used for aesthetics or recreation requires routine fertilizer applications (Rice and Horgan, 2011; Schwartz and Shuman, 2005) to maintain acceptable quality. However, conventionally applied WSFs (Kaminiski et al., 2004; Obreza and Sartain, 2010) are prone to offsite movement through leaching and surface runoff during intense precipitation or excess irrigation (Easton and Petrovic, 2004; Saha et al., 2007). Loss of nutrients such as $\mathrm{N}$ and phosphorus $(\mathrm{P})$ not only reduces soil fertility and thus turfgrass quality

Received for publication 17 July 2019. Accepted for publication 27 Sept. 2019.

Published online 5 November 2019.

${ }^{1}$ School of Plant, Environmental, and Soil Sciences, Louisiana State University Agricultural Center, 226 J.C. Miller Hall, Baton Rouge, LA 70803

K.R.S. is the corresponding author. E-mail: krsanders@ agcenter.lsu.edu.

This is an open access article distributed under the CC BY-NC-ND license (https://creativecommons.org/ licenses/by-nc-nd/4.0/).

https://doi.org/10.21273/HORTTECH04463-19
(Evans and Sorger, 1966; Mengel and Kirkby, 1987), but also contributes to surface and subsurface water impairment. High nutrient concentrations are associated with increased algal blooms incidence, reduced water quality, reduced fish health, decreased oxygen levels, and drinking water contamination (Carpenter et al., 1998; Shuman, 2006; U.S. Environmental Protection Agency, 2019b). Turfgrass managers need information regarding management practices specific to their environments to minimize nutrient movement without compromising turfgrass quality given the increasing awareness surrounding sustainable practices (Andiru et al., 2013) and potentially forthcoming governmental regulations (Louisiana Department of Environmental Quality, 2013; U.S. Environmental Protection Agency, 2019a).

Nutrient loss through turfgrass surface runoff is affected directly by fertilization and irrigation practices. $\mathrm{Al}$ though minimizing applied irrigation can reduce nutrient movement, turfgrass surface runoff is still influenced largely by natural precipitation events for which the timing and depths are difficult to predict. Therefore, substituting WSFs with more slowly available sources, such as CRFs, provides an alternative management practice to reduce nutrient movement. Unlike WSFs, CRFs release nutrients in smaller quantities over longer periods of time (Shuman, 2002). Past research indicates application of CRF materials can reduce nutrient losses in highly managed turfgrass areas (Easton and Petrovic, 2004; Killian et al., 1966; Saha et al., 2007; Shuman, 2003) and may even improve $\mathrm{N}$ uptake. For example, Shuman (2006) found $10.2 \%$ and $0.14 \%$ nitrate was leached after the application of ammonium nitrate vs. sulfur-coated urea, respectively, and concluded the pattern of $\mathrm{N}$ release in a CRF may provide more efficient $\mathrm{N}$ uptake by turfgrass.

The market for CRFs has expanded with several control mechanisms available to turfgrass managers, including semipermeable polymer coatings, occlusion, and slowing hydrolysis of water-soluble compounds (Fu et al., 2018). Polymer coating regulates soluble nutrient release through diffusion of a semipermeable coating and is one of the most

\begin{tabular}{llll}
\hline $\begin{array}{l}\text { Units } \\
\text { To convert U.S. to SI, } \\
\text { multiply by }\end{array}$ & U.S. unit & SI unit & $\begin{array}{l}\text { To convert SI to U.S., } \\
\text { multiply by }\end{array}$ \\
\hline 29.5735 & $\mathrm{fl} \mathrm{oz}$ & $\mathrm{mL}$ & 0.0338 \\
0.3048 & $\mathrm{ft}$ & $\mathrm{m}$ & 3.2808 \\
0.0929 & $\mathrm{ft}^{2}$ & $\mathrm{~m}^{2}$ & 10.7639 \\
3.7854 & gal & $\mathrm{L}$ & 0.2642 \\
2.54 & inch $(\mathrm{es})$ & $\mathrm{cm}$ & 0.3937 \\
25.4 & inch $(\mathrm{es})$ & $\mathrm{mm}$ & 0.0394 \\
1.1209 & $\mathrm{lb} / \mathrm{acre}$ & $\mathrm{kg} \cdot \mathrm{ha}^{-1}$ & 0.8922 \\
112.0851 & $\mathrm{lb} / \mathrm{acre}$ & $\mathrm{mg} \cdot \mathrm{m}^{-2}$ & 0.0089 \\
7.0053 & $\mathrm{oz} / \mathrm{acre}$ & $\mathrm{mg} \cdot \mathrm{m}^{-2}$ & 0.1427 \\
1 & $\mathrm{ppm}$ & $\mathrm{mg} \cdot \mathrm{kg}^{-1}$ & 1 \\
1 & $\mathrm{ppm}$ & $\mathrm{mg} \cdot \mathrm{L}^{-1}$ & 1 \\
$\left({ }^{\circ} \mathrm{F}-32\right) \div 1.8$ & ${ }^{\circ} \mathrm{F}$ & ${ }^{\circ} \mathrm{C}$ & $\left({ }^{\circ} \mathrm{C} \times 1.8\right)+32$ \\
& & &
\end{tabular}


common control mechanisms of CRFs applied today. Nutrient release of polymer-coated CRFs is often calculated based on laboratory performed dissolution tests (Birrenkott et al., 2005); however, in many application sites, environmental factors such as increases in temperature and moisture regulate nutrient release, and thus losses (Medina et al., 2009). In regions along the U.S. Gulf Coast that have a subtropical climate with annual precipitation exceeding 60 inches/year (U.S. Climate Data, 2019), environmental conditions would be expected to increase the rate of nutrient availability from polymer-coated CRFs and potentially alter nutrient losses. More information is needed regarding the performance of CRFs in such subtropical climates, especially given the additional cost of CRFs compared with WSFs (Liu et al., 2017). Therefore, the objective of this study was to compare two fertilizer regimens - a single CRF application and a split application of WSF - to examine the influence fertilizer source has on $\mathrm{N}$ and $\mathrm{P}$ surface runoff losses from hybrid bermudagrass (Cynodon dactylon $\times$ C. transvaalensis), a commonly grown turfgrass for athletic and utility sites.

\section{Materials and methods}

Experimental Design. Two 84d experiments were conducted at the Louisiana State University Agricultural Center Botanic Gardens located in Baton Rouge (lat. 30²4' 25.3" N, long. $91^{\circ} 06^{\prime} 09.5^{\prime \prime} \mathrm{W}$ ) and initiated Sept. 2015 and May 2016. Hybrid bermudagrass was established in two steel runoff trays $(5.9-\mathrm{ft}$ width $\times 20$ - $\mathrm{ft}$ length $\times 1.1$-ft depth) that were subdivided by wooden inserts to form $15-\mathrm{ft}^{2}$ plots $(5.9-\mathrm{ft}$ length $\times 2.5-\mathrm{ft}$ width). Trays were filled with an Opriairie silt topsoil (Alfisol, finesilty, thermic Fragiaquic Glossudalf) that had a $\mathrm{pH}$ of 6.8 with Melich III extractable concentrations of 71.6 $\mathrm{mg} \cdot \mathrm{kg}^{-1} \mathrm{P}$ and $167.1 \mathrm{mg} \cdot \mathrm{kg}^{-1}$ potas$\operatorname{sium}(\mathrm{K})$. Soil was added in two $\approx 6-$ inch layers and was lightly compacted in each tray to a bulk density of 1.21 $\mathrm{g} \cdot \mathrm{cm}^{-3}$. Trays were inclined $3^{\circ}$ inside a rainout shelter to prevent runoff from occurring during natural precipitation events. Ambient air temperature averaged $30{ }^{\circ} \mathrm{C}$. Hybrid bermudagrass was established via sod several months before initiation of the study. Fertilizer treatments consisted of a polymer-coated granular 14N-6.1P-11.6K CRF [Florikote 14-14-14; Florikan, Sarasota, FL (5.90\% nitrate $\mathrm{N}, 8.10 \%$ ammoniacal $\mathrm{N}, 14 \%$ available phosphate; derived from polymer-coated ammonium nitrate, polymer-coated ammonium phosphate, polymer-coated calcium phosphate, and polymer-coated ammonium polyphosphate)], a granular 14N-5.7P-10.8K WSF [Grower's Special 13-13-13; Shell Beach, Many, LA (derived from diammonium phosphate, muriate of potash, and urea)], and an unfertilized control. The CRF was applied at $87 \mathrm{lb} /$ acre $\mathrm{N}$ at the initiation of the study whereas the WSF was applied at 87 $\mathrm{lb} /$ acre $\mathrm{N}$ as a split application (43.5 $\mathrm{lb} /$ acre $\mathrm{N}$ ) at the initiation of the study and 45 DAIF. Treatments were randomized across both trays and fertilizers were applied using shaker jars to ensure even distribution. Fertilizers were not incorporated with irrigation before the first runoff event at 3 DAIF. Hybrid bermudagrass was maintained with a hand trimmer at a height of 2.5 inches, and irrigation was applied only as needed to prevent leaf wilting based on visual inspection.

RAINFALL SIMULATION, MEASUREMENT, AND ANALYSIS. Rainfall simulations were conducted at 3,28 , 56 , and 84 DAIF. Before each rainfall simulation and every 14 DAIF, hybrid bermudagrass quality was recorded. Quality ratings were based on the National Turfgrass Evaluation Program Turfgrass Evaluation Guidelines (Morris and Shearman, n.d.) $(1=$ dead, 5 = acceptable, $9=$ ideal $)$. Rainfall was produced using a modified rainfall simulator system based on the designs of Miller (1987) and Humphry et al. (2002) that allowed rainfall to be simulated over multiple plots within a tray simultaneously. The rainfall simulator produced 3 inches/h using stainless steel nozzles (Fulljet 1/2HH SS 50WSQ; Spraying Systems Co., Wheaton, IL) positioned above each tray for a duration of $30 \mathrm{~min}$ per event. Water for all rainfall simulations and irrigation events was from a filtered municipal source. Runoff collection systems were located at the base of each plot and consisted of two stainless steel, right-angle inserts attached to the tray lip to direct runoff water through
PVC guttering into 18-gal containers for collection. During simulated rainfall events, time until runoff initiation and runoff volumes were recorded.

At the conclusion of each rainfall event, 25-mL aliquots were collected and stored at $4{ }^{\circ} \mathrm{C}$ before analysis. Aliquots were analyzed in triplicate for extractable inorganic nitrate $\left(\mathrm{NO}_{3}{ }^{-}\right)-\mathrm{N}$ and ammonium $\left(\mathrm{NH}_{4}{ }^{+}\right)$ $\mathrm{N}$ using the inorganic $\mathrm{N}$ microplate method (Hood-Nowotny et al., 2010). Measurements of $\mathrm{NO}_{3}{ }^{-}-\mathrm{N}$ and $\mathrm{NH}_{4}{ }^{+}-\mathrm{N}$ data were combined and are referred to as inorganic $\mathrm{N}$ henceforth. Water subsamples were also submitted to the Louisiana State University Soil Testing and Plant Analysis Laboratory (Baton Rouge) for direct injection for quantitation of DTP using inductively coupled plasma optical emission spectroscopy (ARCOS Model FH E12; SPECTRO, Kleve, Germany).

Statistical analysis. The study was arranged in a completely randomized design with three replications for each of the three fertilizer treatments. Data from the measurements of hybrid bermudagrass quality, the time until runoff initiation, runoff depth, and inorganic $\mathrm{N}$ and DTP losses were analyzed using the mixed procedure in the statistical software of SAS (version 9.4; SAS Institute, Cary, NC) for the fixed factors fertilizer source and date. Data that occurred over time were analyzed using repeated measures; the year the experiments in the study were conducted was a random factor. If factors were significant ( $\alpha=0.05$ or 0.1 ) within the statistical model, mean separations were accomplished using Tukey's honestly significant difference procedure $(\alpha=0.05)$.

\section{Results and discussion}

HYBRID BERMUDAGRASS RESPONSE TO FERTILIZER TREATMENT. When developing a fertility management plan, turfgrass managers may consider substituting traditional WSFs with CRFs to maintain high-quality turfgrass. In this study, hybrid bermudagrass quality increased for all fertilizer treatments the first 56 DAIF before declining the remainder of the experimental period, as shown in Fig. 1. In general, CRF and WSF-hybrid bermudagrass were comparable throughout the 84-d study, with CRF-hybrid bermudagrass exhibiting a slightly higher quality compared with WSF-hybrid 


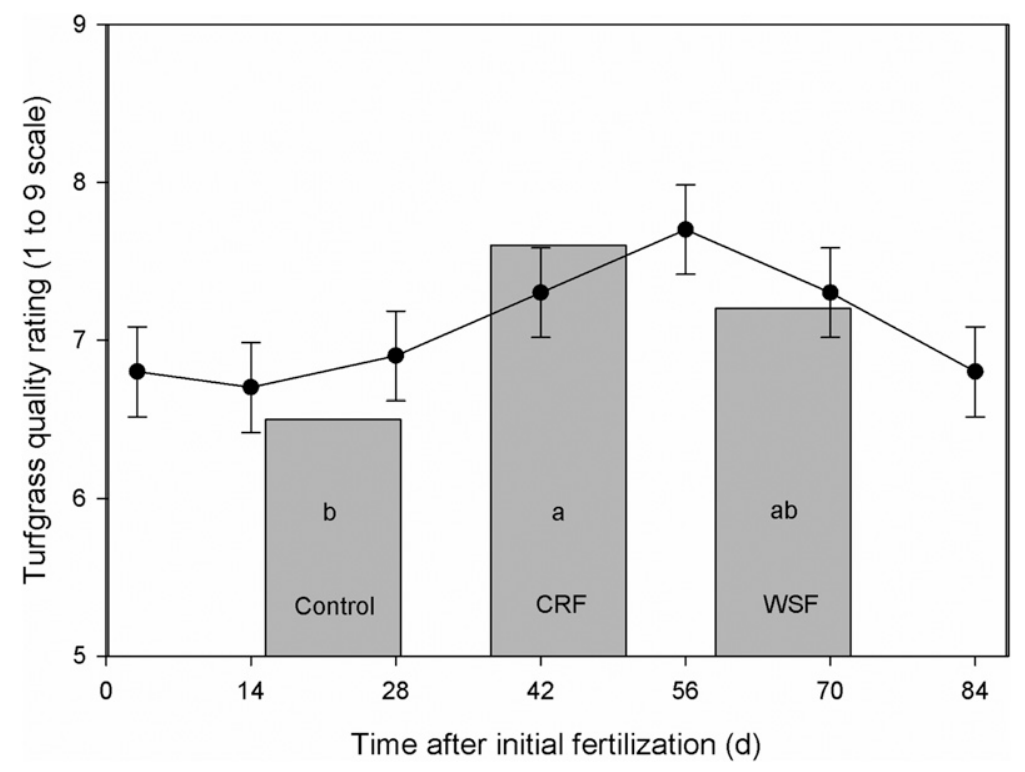

Fig. 1. The line graph illustrates the average turfgrass quality $(1=$ dead; $5=$ acceptable; 9 = ideal) of hybrid bermudagrass across treatments of no fertilizer (control), a controlled-release fertilizer (CRF) applied at $87 \mathrm{lb} / \mathrm{acre}^{\left(97.5 \mathrm{~kg} \cdot \mathrm{ha}^{-1}\right)}$ nitrogen $(\mathrm{N})$ at $0 \mathrm{~d}$ after initial fertilization (DAIF), or a water-soluble fertilizer (WSF) applied at $87 \mathrm{lb} /$ acre $\mathrm{N}$ as a split application [43.5 lb/acre $\left(48.76 \mathrm{~kg} \cdot \mathrm{ha}^{-1}\right)$ $\mathrm{N}]$ at 0 and 45 DAIF over an 84-d experimental period. Data points were fitted with SE bars at $P=0.05$. The bar graph illustrates the average turfgrass quality of hybrid bermudagrass for each fertilizer treatment for the 84-d experimental period. Means with different letters are significantly different according to Tukey's honestly significant difference procedure at $P=0.10$.

bermudagrass and untreated hybrid bermudagrass, which had the lowest quality, if the significance level is adjusted to $P=0.1(P=0.06)$ (Table 1$)$. Although not observed in this study, applying WSFs can lead to a surge in turfgrass quality compared with CRFs during the initial weeks after application for several hybrid bermudagrass (Hollingsworth et al., 2005) and other warm-season turfgrass species, with differences in quality dissipating over time (Saha et al., 2007). The similarity in hybrid bermudagrass quality observed in this study between fertilizers, however, is a function of the application rates and nutrient release timings. The CRF was applied as a single application at $87 \mathrm{lb} / \mathrm{acre}$, compared with WSF, which was applied as two applications at $43.5 \mathrm{lb} /$ acre $\mathrm{N}$ at 0 and 45 DAIF. Faster release of CRF nutrients resulting from warm temperatures and high soil moisture, from the first rainfall simulation 3 DAIF, provided sufficient $\mathrm{N}$ to minimize discrepancies in WSF-hybrid bermudagrass quality. Therefore, nutrient release from the CRF, which is designed to release nutrients in smaller quantities for plant uptake (Shuman, 2006), occurred slightly faster than the 90-d duration stated on the manufacturer's label, even though the CRF did extend nutrient release over time to maintain high-quality hybrid bermudagrass compared with WSF applications.

N AND P SURFACE RUNOFF LOSSES. Turfgrass managers must also consider potential environmental impacts when implementing fertility practices, especially given the recent focus within the turfgrass industry on fertilization practices contributing to pollution (Trenholm and Unruh, 2005) of surface and subsurface waters. Surface runoff from turfgrass established on fine-texture soil is known to be influenced by soil moisture and precipitation duration, and fluctuations in those environmental conditions consequently affect runoff initiation and volumes (Linde, 1998). In this study, runoff initiation occurred within 3.3 to $5.5 \mathrm{~min}$, with runoff volumes ranging from 40.9 to $50.3 \mathrm{~L}$ (depth, 2.9-3.6 cm) across all rainfall simulations with no effect resulting from fertilizer treatment. Other studies that have examined nutrient losses from turfgrasses via surface runoff correlated factors such as sward density (Easton and Petrovic, 2004; Gross et al., 1990) and groundcover (Burwell et al., 2011 ) to variation in runoff initiation, volumes, and sediment loading. Prostrate-growing turfgrass species, such as hybrid bermudagrass, form dense canopies that obstruct water flow for greater infiltration, delay the onset of runoff, decrease runoff volume, and trap sediment (Burwell et al., 2011; Easton and Petrovic, 2004; Linde and Watschke, 1997). In the case of this study, fertilizers were applied to established hybrid bermudagrass, which resulted in similar runoff initiation and volumes among treatments at each rainfall simulation event. This reduced potential confounding effects that allowed for a more direct comparison of fertilizer effects on nutrient losses.

The benefit of CRFs vs. WSFs is the reduction in initial nutrient losses from surface runoff. Runoff from the first rainfall simulation 3 DAIF accounted for $72.7 \%$ and $75.3 \%$ of cumulative inorganic $\mathrm{N}$ and DTP losses, respectively, from WSF-hybrid bermudagrass, compared with $44.4 \%$ and $32 \%$, respectively, from CRFhybrid bermudagrass, despite CRF being applied as a single application, as shown in Figs. 2 and 3 . High nutrient losses occurring from initial surface runoff events is common postapplication of fertilizers and is consistent with findings from similar research that has measured soluble nutrient losses from turfgrasses (Linde and Watschke, 1997; Shuman, 2006). For example, Easton and Petrovic (2004) reported the greatest nutrient concentration losses occurred during the first runoff event for kentucky bluegrass (Poa pratensis), independent of fertilizer source, with nutrient losses exhibiting reductions in nutrient concentrations over time. Similarly, in this study, the effect of fertilizer on nutrient losses declined with subsequent runoff events, with losses declining to ranges of 149.83 to $47.14 \mathrm{mg} \cdot \mathrm{m}^{-2}$ inorganic $\mathrm{N}$ and 70.95 to $48.16 \mathrm{mg} \cdot \mathrm{m}^{-2}$ DTP for both CRFand WSF-hybrid bermudagrass.

A significant spike in nutrient losses was not evident after the second application of WSF (45 DAIF) during the rainfall simulation 56 DAIF. Hybrid bermudagrass fertilized with WSF resulted in inorganic $\mathrm{N}$ losses of $47.14,79.49$, and $88.85 \mathrm{mg} \cdot \mathrm{m}^{-2}$ at 


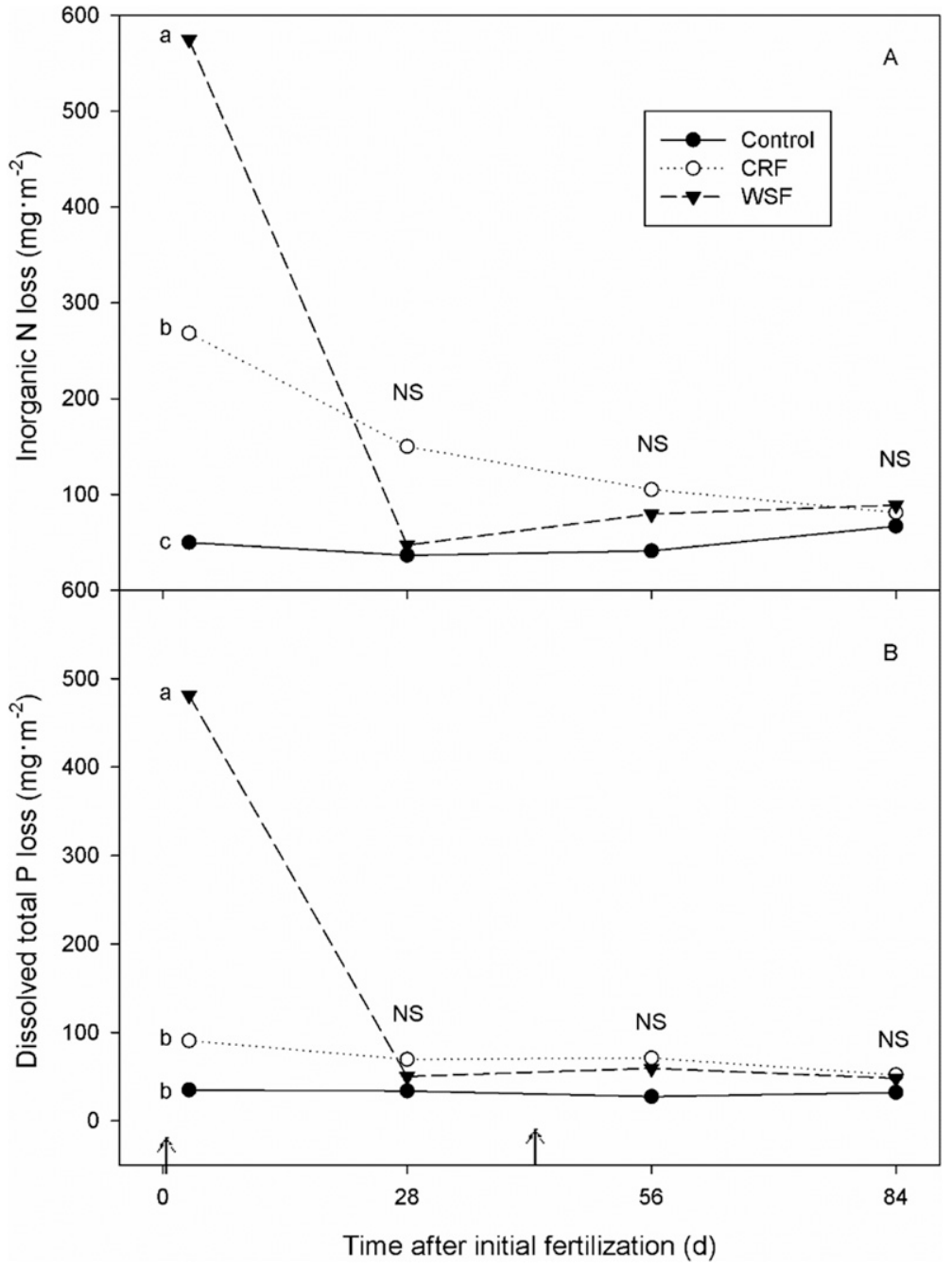

Fig. 2. (A) Inorganic nitrogen $(\mathrm{N})$ and $(\mathrm{B})$ dissolved total phosphorus (P) surface runoff losses from hybrid bermudagrass treated with no fertilizer (control), a controlled-release fertilizer (CRF) applied at $87 \mathrm{lb} /$ acre $\left(97.5 \mathrm{~kg} \cdot \mathrm{ha}^{-1}\right) \mathrm{N}$ at $0 \mathrm{~d}$ after initial fertilization (DAIF), or a water-soluble fertilizer (WSF) applied at $87 \mathrm{lb} /$ acre $\mathrm{N}$ as a split application [43.5 lb/acre $\left.\left(48.76 \mathrm{~kg} \cdot \mathrm{ha}^{-1}\right) \mathrm{N}\right]$ at 0 and 45 DAIF during 30 -min rainfall simulations at an intensity of 3 inches $(76.2 \mathrm{~mm})$ per hour at 3, 28, 56, and 84 DAIF. Means not followed by the same letter are significantly different according to Tukey's honestly significant difference procedure at $P=0.05 ; 1 \mathrm{mg} \cdot \mathrm{m}^{-2}=0.1427 \mathrm{oz} /$ acre $=0.0089 \mathrm{lb} /$ acre $(\mathrm{NS}=$ not significant). The arrows designate WSF split applications at $43.5 \mathrm{lb} / \mathrm{acre} \mathrm{N}$ at 0 and $45 \mathrm{DAIF} ; 1 \mathrm{mg} \cdot \mathrm{m}^{-2}=0.1427 \mathrm{oz} /$ acre $=0.0089 \mathrm{lb} /$ acre .

28,56 , and 84 DAIF, respectively; DTP losses were $50.14,59.46$, and $48.16 \mathrm{mg} \cdot \mathrm{m}^{-2}$, respectively. Unlike the initial WSF application, nutrients losses from the second WSF application may have been affected by incorporation from irrigation that was applied to prevent hybrid bermudagrass declining between WSF application and the first rainfall simulation after fertilizer application at 56 DAIF. Incorporating nutrients using irrigation moves nutrients into the thatch and soil for increased binding and plant uptake (Shuman, 2006), and can reduce nutrient losses. The
DAIF, compared with WSF-hybrid bermudagrass.

Although CRF-hybrid bermudagrass did exhibit decreased nutrient losses compared with WSF-hybrid bermudagrass, there were differences in $\mathrm{N}$ and $\mathrm{P}$ loading. Initial inorganic $\mathrm{N}$ losses from CRF-hybrid bermudagrass were nearly $3 \times$ the initial DTP losses during the first runoff event and accounted for $113.3 \%$ increased cumulative $\mathrm{N}$ losses vs. P. A similar trend between cumulative $\mathrm{N}$ and $\mathrm{P}$ loading was also present for WSF-hybrid bermudagrass, but was not as pronounced as CRF-hybrid bermudagrass. $\mathrm{N}$ in the form of $\mathrm{NO}_{3}{ }^{-}$is poorly retained in the soil and susceptible to movement (Paramasivam and Alva, 1997). Easton and Petrovic (2004) also found $\mathrm{N}$ losses to be greater relative to $\mathrm{P}$ when either a readily available urea or sulfur-coated urea were applied to kentucky bluegrass or perennial ryegrass (Lolium perenne). Although the CRF did regulate nutrient release over an extended period compared with the high nutrient losses from WSF, CRF and WSF exhibited statistically comparable cumulative inorganic $\mathrm{N}$ losses at 603.99 and 790.24 $\mathrm{mg} \cdot \mathrm{m}^{-2}$, respectively. However, CRF showed potential to reduce $\mathrm{N}$ losses, especially given WSF was not incorporated into the soil.

In contrast, CRF reduced cumulative DTP losses to $283.06 \mathrm{mg} \cdot \mathrm{m}^{-2} \mathrm{vs}$. $638.90 \mathrm{mg} \cdot \mathrm{m}^{-2}$ from WSF. P complexes readily with other elements in the soil, and is absorbed and retained in the soil (King, 2001), making it less available for movement and loss through surface runoff on denser turfs. $\mathrm{P}$ has a greater potential for contamination of coastal ecosystems (Carpenter et al., 1998), as is noted by the difference in acceptable surface water quality criteria $\left(0.06 \mathrm{mg} \cdot \mathrm{L}^{-1} \mathrm{~N}\right.$ vs. 0.57 $\mathrm{mg} \cdot \mathrm{L}^{-1} \mathrm{P}$ ) outlined for U.S. Environmental Protection Agency Ecoregion $\mathrm{X}$ [Texas-Louisiana Coastal and Mississippi alluvial plains (U.S. Environmental Protection Agency, 2019a)]. Therefore, the use of CRF as a means to reduce $\mathrm{P}$ surface runoff loss has application and should be considered for use in areas subject to surface runoff. In addition to using CRF sources to reduce $\mathrm{P}$ losses through surface runoff, other research has suggested reducing $\mathrm{N}$ and $\mathrm{P}$ application rates to meet crop needs more effectively (Carpenter et al., 1998; Shuman, 2003) and emphasized the 


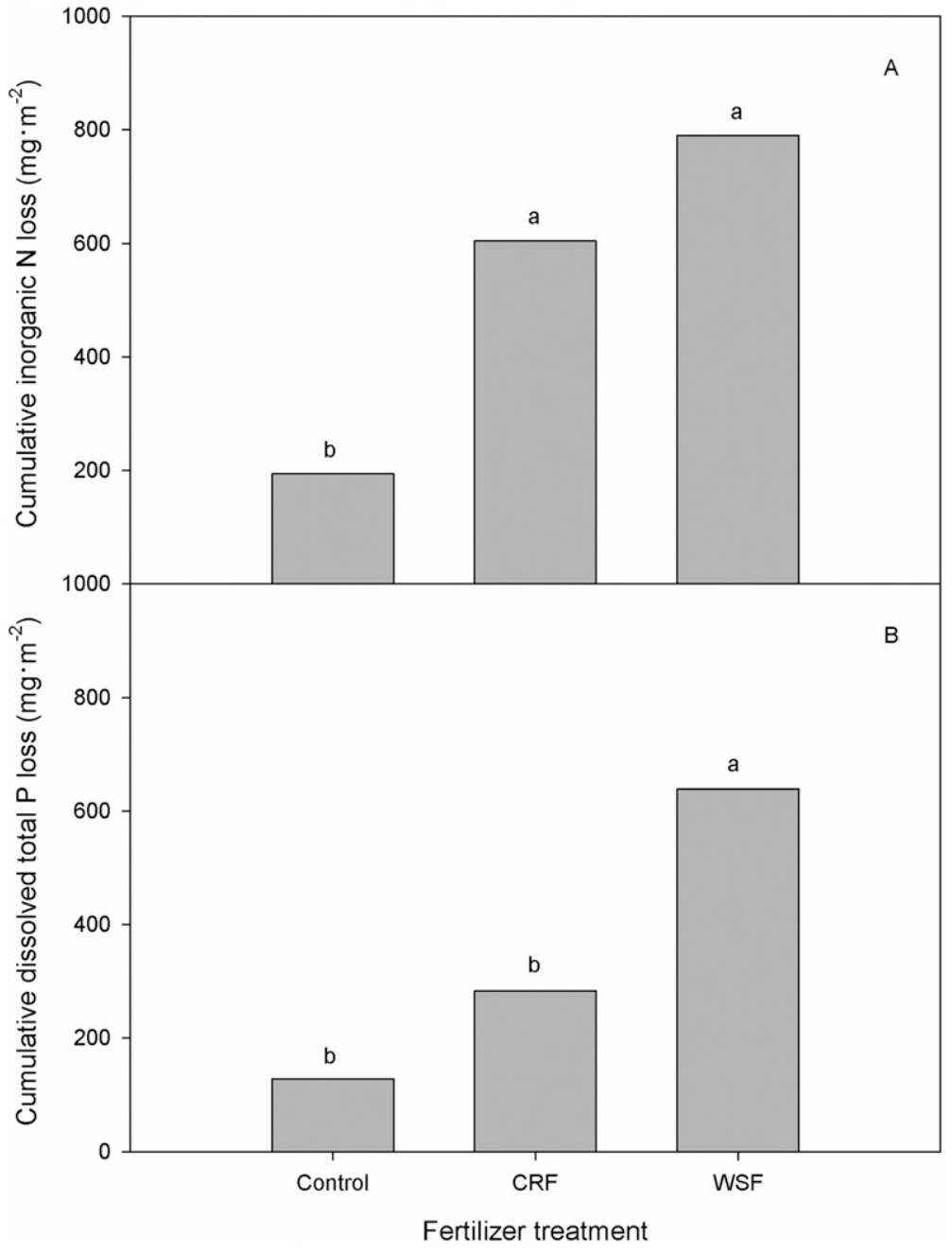

Fig. 3. (A) Cumulative inorganic nitrogen (N) and (B) dissolved total phosphorus (P) surface runoff losses from hybrid bermudagrass treated with no fertilizer (control), a controlled-release fertilizer (CRF) applied at $87 \mathrm{lb} / \mathrm{acre}\left(97.5 \mathrm{~kg} \cdot \mathrm{ha}^{-1}\right)$ $\mathrm{N}$ at $0 \mathrm{~d}$ after initial fertilization (DAIF), or a water-soluble fertilizer (WSF) applied at $87 \mathrm{lb} /$ acre $\mathrm{N}$ as a split application [43.5 lb/acre $\left(48.76 \mathrm{~kg} \cdot \mathrm{ha}^{-1}\right) \mathrm{N}$ ] at 0 and 45 DAIF after 30-min rainfall simulations at an intensity of 3 inches $(76.2 \mathrm{~mm})$ per hour at $3,28,56$, and 84 DAIF. Means not followed by the same letter are significantly different according to Tukey's honestly significant difference procedure at $P=0.05 ; 1 \mathrm{mg} \cdot \mathrm{m}^{-2}=0.1427 \mathrm{oz} /$ acre $=0.0089 \mathrm{lb} /$ acre .

Table 1. Statistical analysis of fixed effects according to Tukey's honestly significant difference procedure at $\boldsymbol{P}=\mathbf{0 . 0 5}$ for turfgrass quality, nitrogen $(\mathrm{N})$ losses, and phosphorus losses of hybrid bermudagrass treated with no fertilizer (control), a controlled-release fertilizer applied at $87 \mathrm{lb} / \mathrm{acre}\left(97.5 \mathrm{~kg} \cdot \mathrm{ha}^{-1}\right) \mathrm{N}$ at $0 \mathrm{~d}$ after initial fertilization (DAIF), or a water-soluble fertilizer applied at 87 $\mathrm{lb} /$ acre $\mathrm{N}$ as a split application [43.5 lb/acre $\left.\left(48.76 \mathrm{~kg} \cdot \mathrm{ha}^{-1}\right) \mathrm{N}\right]$ at 0 and 45 DAIF, and subjected to 30 -min rainfall simulations at an intensity of 3 inches $(76.2 \mathrm{~mm})$ per hour at $3,28,56$, and 84 DAIF over an 84-d experimental period.

\begin{tabular}{lccc}
\hline & Turfgrass quality & Nitrogen losses & Phosphorus losses \\
\cline { 2 - 4 } Analysis of variance effects & \multicolumn{3}{c}{$($ Pvalue $)$} \\
\hline Fertilizer treatment (F) & 0.0607 & 0.0025 & 0.0028 \\
Date (D) & 0.0469 & $<0.0001$ & $<0.0001$ \\
F $\times$ D & 0.9151 & $<0.0001$ & $<0.0001$ \\
\hline
\end{tabular}

importance of testing soils for $\mathrm{P}$ before applying fertilizer (Bierman et al., 2010).
Turfgrass managers should implement management practices that can curb nutrient losses without sacrificing turfgrass quality. This is not to say that all turfgrass managers should only apply CRFs to achieve this purpose. However, if WSFs are applied, turfgrass managers should consider incorporating nutrients through irrigation to reduce transport of nutrients offsite via surface runoff. This is particularly effective for soil-bound $\mathrm{P}$ that can be filtered by greater hybrid bermudagrass groundcover. The advantages of CRF application vs. WSF were the reduction in initial nutrient losses, the reduction in number of fertilizer applications, and maintenance of hybrid bermudagrass quality at or above WSF-hybrid bermudagrass. Furthermore, irrigation incorporation may not be necessary for CRF application to reduce fertilizer losses. Therefore, based on the findings of this study, the application of polymer-coated CRF provides a suitable alternative to WSF as a best management practice for turfgrass managers to maintain highquality turfgrass and minimize surface runoff movement of nutrients.

\section{Literature cited}

Andiru, G., P. Jourdan, J. Frantz, and C. Pasian. 2013. Longevity of controlledrelease fertilizer influences the growth of bedding impatiens. HortTechnology 23: 157-164.

Bierman, P., A. Hollman, P. Pagliari, B. Horgan, and C. Rosen. 2010. Phosphorus runoff from turfgrass as affected by phosphorus fertilization and clipping management. J. Environ. Qual. 39:282-292.

Birrenkott, B., G. McVey, and J. Craig. 2005. A leach collection system to track the release of nitrogen from controlledrelease fertilizers in container ornamentals. HortScience 40:1887-1891.

Burwell, R., J. Beasley, L. Gaston, S. Borst, R. Sheffield, R. Strahan, and G. Munshaw. 2011. Losses of surface runoff, total solids, and nitrogen during hybrid bermudagrass establishment on levee embankments. J. Environ. Hort. 40:1241-1248.

Carpenter, S., N. Caraco, D. Correll, R. Howarth, A. Sharpley, and V. Smith. 1998. Nonpoint pollution of surface waters with phosphorus and nitrogen. Ecol. Appl. 8:559-568.

Easton, Z. and A. Petrovic. 2004. Fertilizer source effect on ground and surface water quality in drainage from turfgrass. J. Environ. Qual. 33:645-655.

Evans, H. and G. Sorger. 1966. Role of mineral elements with emphasis on the 
univalent cations. Annu. Rev. Plant Physiol. 17:47-76.

Fu, J., C. Wang, D. Chen, X. Chen, and Z. Huang. 2018. Classification research and types of slow controlled release fertilizers (SRFs) used: A review. Commun. Soil Sci. Plant Anal. 49:2219-2230.

Gross, C., J. Angle, and M. Welterlen. 1990. Nutrient and sediment losses from turfgrass. J. Environ. Qual. 19:663-668.

Hollingsworth, B., R. Walker, and E. Guertal. 2005. Cultural management and nitrogen source effects on ultradwarf hybrid bermudagrass cultivars. Crop Sci. 45:486-493.

Hood-Nowotny, R., N. Hinko-Najera, E. Inselbacher, W. Wanek, and P. Lachouani. 2010. Alternative methods for measuring inorganic, organic, and total dissolved nitrogen in soil. Soil Sci. Soc. Amer. J. 74:1018-1027.

Humphry, J., T. Daniel, D. Edwards, and A. Sharpley. 2002. A portable rainfall simulator for plot-scale runoff studies. Appl. Eng. Agr. 18:199-204.

Kaminiski, J., C. Bigelow, and P. Dernoeden. 2004. Soil amendments and fertilizer source effects on creeping bentgrass establishment, soil microbial activity, thatch, and disease. HortScience 39:620626.

Killian, K., O. Attoe, and L. Engelbert. 1966. Urea formaldehyde as a slowly available form of nitrogen for kentucky bluegrass. Agron. J. 58:204-206.

King, K. 2001. Impact of a turfgrass system on nutrient loadings to surface water. J. Amer. Water Resource Assn. 37:629640.

Linde, D. 1998. Surface runoff comparison between creeping bentgrass and perennial ryegrass turf. J. Turfgrass Mgt. $2: 11-33$.

Linde, D. and T. Watschke. 1997. Nutrients and sediment in runoff form creeping bentgrass and perennial ryegrass turfs. J. Environ. Qual. 26:1248-1254.

Liu, G., L. Zotarelli, Y. Li, D. Dinkins, Q. Wang, and M. Ozores-Hampton. 2017. Controlled-release and slow-release fertilizers as nutrient management tools. Univ. Florida, Inst. Food Agr. Sci. Ext., Publ. HS1255. 15 June 2019. <http:// edis.ifas.ufl.edu/hs1255>.

Louisiana Department of Environmental Quality. 2013. Louisiana nutrient management strategy. 15 June 2019. <https://deq.louisiana.gov/assets/docs/ Water/2013-01-18_FACTSHEET_ LANUTRIENTSTRATEGY_3.pdf>.

Medina, L., T. Obreza, and J. Sartain. 2009. Estimation of release properties of slowrelease fertilizer materials. HortTechnology 9:13-15

Mengel, K. and E. Kirkby. 1987. Principles of plant nutrition. International Potash Institute, Worblaufen-Bern, Switzerland.

Miller, W. 1987. A solenoid-operated, variable intensity rainfall simulator. Soil Sci. Soc. Amer. J. 51:832-834.

Morris, K. and R. Shearman. (n.d.). NTEP turfgrass evaluation guidelines. 15 June 2019. <http://www.ntep.org/pdf/ ratings.pdf $>$.

Obreza, T. and J. Sartain. 2010. Improving nitrogen and phosphorus fertilizer use efficiency for Florida's horticultural crops. HortTechnology $2: 23-33$.

Paramasivam, S. and A. Alva. 1997. Leaching of nitrogen forms from controlled-release nitrogen fertilizers. Commun. Soil Sci. Plant Anal. 28:1663-1674.

Rice, P. and B. Horgan. 2011. Nutrient loss with runoff from fairway turf: An evaluation of core cultivation practices and their environmental impact. Environ. Toxicol. Chem. 30:2473-2480.

Saha, S., J. Unruh, and L. Trenholm. 2007. Effect of fertilizer source on nitrate leaching and st. augustinegrass turfgrass quality. HortScience 42:1478-1481.

Schwartz, L. and L. Shuman. 2005. Predicting runoff and associated nitrogen losses from turfgrass using the root zone water quality model (RZWQM). J. Environ. Qual. 34:350-358.

Shuman, L. 2002. Phosphorus and nitrate nitrogen in runoff following fertilizer application to turfgrass. J. Environ. Qual. 31:1710-1715.

Shuman, L. 2003. Fertilizer source effects on phosphate and nitrate leaching through simulated golf greens. Environ. Pollut. 125:413-421.

Shuman, L. 2006. Normal and flush irrigation effects on nitrogen leaching from simulated golf greens in the greenhouse. Commun. Soil Sci. Plant Anal. 37:605-619.

Trenholm, L. and J. Unruh. 2005. Warmseason turfgrass response to fertilizer rates and sources. J. Plant Nutr. 28:991-999.

U.S. Climate Data. 2019. Climate Baton Rouge-Louisiana, weather averages. 15 June 2019. <https://www.usclimatedata. com/climate/baton-rouge/louisiana/ united-states/usla0033>.

U.S. Environmental Protection Agency. 2019a. Correction of significant figures in aggregate ecoregional criteria recommendations. 15 June 2019. <https:// www.epa.gov/sites/production/files/ 2014-08/documents/criteria-nutrientecoregions-correction.pdf $>$.

U.S. Environmental Protection Agency. $2019 \mathrm{~b}$. Nutrient pollution, the problem. 15 June 2019. <https://www.epa.gov/ nutrientpollution/problem $>$. 